\title{
A FRISS DIPLOMÁSOK EMBERI TŐKE BERUHÁZÁSAINAK MUNKAERŐ-PIACI HATÁSA
}

\section{Szerző:}

Biszkuné Orosz Tóth Ildikó

Debreceni Egyetem

Szerző e-mail címe:

biszkune.ildiko@foh.unideb.hu

\section{Lektorok:}

Koncz István

Professzorok az Európai Magyarországért

Mező Ferenc

Debreceni Egyetem

Mező Katalin

Debreceni Egyetem

Schéder Veronika

Debreceni Egyetem

Biszkuné Orosz Tóth Ildikó (2016):A friss diplomások emberi tőke beruházásának munkaerőpiaci hatása, Különleges Bánásmód, II. évf. 2016/3. szám, 5-13. DOI 10.18458/KB.2016.3.5

\begin{abstract}
Absztrakt
Tanulmányunkban a frissdiplomások munkaeröpiaci elhelyezkedésének nehézségeit, lehetöségeit kívánjuk részletesen feltárni, megvizsgálni. A felmérés elkészítéséhez a Debreceni Egyetemen végzett egészségügyi ápolók körében végeztünk adatgyüjtéseket. Elsődleges célunk a megszerzett végzettség hasznosságának mérése, azaz, a vizsgálat alanyai milyen mértékben tudtak a megszerzett szakképpesítésnek megfelelö munkakört betölteni. A feltevéseinket statisztikai módszerekkel igyekeztünk alátámasztani.
\end{abstract}

Kulcsszavak: Debreceni Egyetem, egészségügy, frissdiplomás, munkaerő

Diszciplinák: pedagógia, közgazdaságtan

\begin{abstract}
EFFECTS ON JOB MARKET OF FRESH GRADUATES' HUMAN CAPITAL INVESTMENT

In our study we would like to reveal the difficulties of getting a job as a fresh graduat. We conducted a survey among health care graduates at the University of Debrecen. Our goal is to measure the value of qualification of medical staff and to measure usefulness of the qualification and to see how many graduates could get a job according to their qualification. Our hypothesis is confirmed by statistical measurements.
\end{abstract}

Keywords: University of Debrecen, health care, graduate, human resource

Disciplines: pedagogy, economy 
Tervezett vizsgálatunkban a frissen diplomázott hallgatók munkaerő-piaci életútjának kezdőpontjára fókuszálunk. Arra vagyunk kíváncsiak, hogy a megszerzett diploma birtokában hogyan kezdődik az érintettek munkaerö-piaci karrierje. Vajon végzettségüknek megfelelö szakterületen helyezkednek-e el? Vajon munkaerő-piaci aspirációjuk adekvátan kapcsolódik felsőfokú tanulmányaikhoz? Arra is választ keresünk, hogy a hallgatói eredményesség meghatározza-e az elhelyezkedés kimenetelét. Kérdésként vetődik fel az is, hogy a hazai vagy a nemzetközi munka világa vonzza-e inkább a végzett diplomásokat. Ez utóbbi kérdésfelvetés különösen aktuális a vizsgálatunk alanyai, vagyis az egészségügyi tudományterületen végzettek vonatkozásban.

Témánk elméleti hátterét elsősorban az emberi és társadalmi töke elméletek adják. Az emberi tőkébe történő beruházás megtérülésének kérdésének megközelítése több diszciplína mentén értelmezhető pl.: közgazdasági, szociológiai, neveléstudományi. Számos hazai empirikus vizsgálódás eredménye (Kovács 1983; Kertesi és Köllő 2001; Szanyi 2005; Galasi 2004; Kertesi és Varga 2005; Polónyi 2008; Györgyi 2014) alapján kijelenthetjük, hogy az iskolai végzettség, a munkaerő-piaci tapasztalat jelentősen befolyásolja az elhelyezkedési esélyeket (R. Fedor 2015). Ennek értelmében a diplomával rendelkező pályakezdő fiatalok elhelyezkedési esélyei kedvezőbbek a diplomával nem rendelkező társaiknál. A hazai adatok alapján egyértelműen kijelenthetjük, hogy a tudásba történő befektetés megtérül a munkaeröpiacon, hiszen a különböző iskolai végzettségi fokozatokat összevetve azt tapasztaljuk, hogy az egyetemi diplomával rendelkezők körében a legmagasabb (közel 80\%) a foglalkoztatottak aránya (lásd: 1 . táblázat).

1. táblázat: Foglalkoztatási ráta legmagasabb iskolai végzettség szerint (2006-2015) KSH adatok alapján. Forrás: Net1.

\begin{tabular}{|l|c|c|c|c|c|c|c|c|}
\hline Év & $\begin{array}{c}8 \text { általános } \\
\text { iskolánál } \\
\text { kevesebb }\end{array}$ & $\begin{array}{c}\text { Általános } \\
\text { iskola 8. } \\
\text { osztálya }\end{array}$ & $\begin{array}{c}\text { Szakiskola és } \\
\text { szakmunkásképző }\end{array}$ & Gimnázium & $\begin{array}{c}\text { Egyéb } \\
\text { érettségi }\end{array}$ & Főiskola & Egyetem & Összesen \\
\hline Együtt & & & & & & & & \\
\hline 2006 & 5,2 & 22,5 & 68,7 & 42,5 & 66,4 & 75,5 & 74,8 & 50,9 \\
\hline 2007 & 4,9 & 22,0 & 67,5 & 42,1 & 65,9 & 73,4 & 74,4 & 50,7 \\
\hline 2008 & 5,1 & 22,0 & 65,2 & 40,6 & 64,5 & 72,4 & 75,2 & 50,0 \\
\hline 2009 & 5,6 & 20,5 & 62,4 & 40,0 & 62,7 & 71,8 & 72,8 & 48,8 \\
\hline 2010 & 7,8 & 20,5 & 61,4 & 39,1 & 61,8 & 71,0 & 72,3 & 48,7 \\
\hline 2011 & 6,7 & 20,8 & 60,8 & 39,7 & 61,5 & 71,3 & 73,7 & 49,1 \\
\hline 2012 & 8,1 & 21,2 & 60,7 & 41,0 & 62,3 & 71,2 & 73,0 & 50,1 \\
\hline 2013 & 9,8 & 22,0 & 60,9 & 42,5 & 63,1 & 70,5 & 74,2 & 51,2 \\
\hline 2014 & 11,8 & 25,9 & 63,2 & 45,3 & 65,7 & 71,3 & 75,3 & 54,1 \\
\hline 2015 & 15,1 & 28,2 & 63,9 & 48,1 & 67,0 & 72,5 & 77,5 & 55,9 \\
\hline
\end{tabular}

Az elmúlt évtizedekben jelentős demográfiai változások jellemezték hazánkat, többek között csökkent a születések száma, kitolódott a házasságkötések az első gyermekvállalás időpontja. Csökken a házasságkötések száma és továbbra is igen magas a válások aránya. A válások egyre növekvő számának egyenes következménye az egyszülős családok gyarapodása, mely a szülők társadalmi tőkéjének hiányos átadását eredményezi. Ezt a jelenséget Coleman a társadalmi töke strukturális hiányosságaként értelmezi. Tervezett kutatásunkban vizsgálni kívánjuk, hogy a család szerkezetének jellege hatással van-e a fiatalok elhelyezkedésére.

A társadalmi tőke abban különbözik leginkább a többi tőkefajtától, hogy a cselekvők közötti viszonyokban ölt testet, tehát nem lelhető fel sem magukban a cselekvőkben, sem a termelés 
anyagi eszközeiben, tehát Coleman a kapcsolatok fontosságát hangsúlyozza, számos példát hoz fel ennek demonstrálására (Coleman 1996,1998). A családok magas jövedelme és a szülők magas iskolai végzettsége alacsony társadalmi tőkével párosulva nem tudja kifejteni az előzetesen elvárt hatást. A magas társadalmi tőke azonban, kapcsolódva a már említett előnyökhöz, képes megsokszorozni azok erejét (Coleman 1996). Esettanulmányok egész sorát hozták fel példaként annak bizonyítására, hogy a szülők - különösképpen az édesanya - magas társadalmi tőkéje képes kiegyenlíteni egyéb hátrányokat. Még a szegény és csonka családok esetében is jó eredménnyel végezték a gyerekek iskolai tanulmányaikat, ha az anya és a gyermeke között erős érzelmi kapcsolat állt fenn és a családot sok barát vette körül.

\section{Elméleti háttér}

A téma vizsgálatának elméleti háttere multidiszciplináris jellegü, mivel számos tudományterület szolgál alapjául a vizsgálandó területnek, többek között: pedagógia, szociológia, közgazdaságtan, jog. Mindemellett a tervezett kutatásunk elméleti alapjait az emberi és társadalmi tőke elméletek, valamint a korábbi hazai és külföldi kutatási eredmények adják. Kutatási tervünkben a tőke elméleteket emeljük ki.

A társadalmi tőke meghatározásának négy irányvonala különböztethető meg, a közgazdaságtani, a szociológiai, a politológiai és az antropológiai megközelítés. A társadalmi tőkének nincs egyetlen konkrét definíciója, a különböző szempontok szerint vizsgálódó szociológiai, antropológiai, politológiai és közgazdasági irányultságú kutatások különböző aspektusát ki-emelve definiálják (Imre 2001; Pusztai 2009). Munkánkban nem mutatjuk be a lehetséges definíciók teljes palettáját, elsősorban Bourdieu (1998), Coleman (1996), Granovetter (1988) elméleteire hivatkozunk.

Bourdieu (1998) a következő egymásba konvertálható tökeformákat különböztette meg:

Gazdasági tőke - konvertálás: közvetlenül pénzre

- intézményesedésre hajlam: különösen a tulajdonjogi formában

Kulturális tőke - konvertálás: bizonyos feltételek mellett gazdasági tőkévé

- intézményesedésre hajlam: az iskolai végzettségi titulusok formájában

Társadalmi tőke - konvertálás: bizonyos feltételek mellett gazdasági tőkévé

- intézményesedésre hajlam: nemesi címek formájában

Gazdasági tőke (közgazdaság-elmélet):

- gazdasági gyakorlatból eredeztetett fogalom, a kapitalizmus találmánya

- a közgazdaság-elmélet társadalmi csereviszonyok két formáját különíti el:

a.) gazdasági - egyszerü árucserére, melyet a profit maximalizálása és (gazdasági) önzés vezérel

b.) nem gazdasági - a társadalmi csereviszonyok összes többi formája, nem gazdasági, önzetlen viszony

\section{Kulturális töke:}

-Inkorporált kulturális tőke - bensővé tett, a szervezet tartós készségei

-Objektivált kulturális tőke - tárgyiasult, pl. képek, könyvek, eszközök, gépek, stb. elméletek és azok kritikái, problematikák nyomán valósultak meg 
-Intézményesült kulturális tőke - tárgyiasult forma, de elkülönített kezelése célszerü, mert sajátos tulajdonságokat kölcsönöz az általa garantált kulturális tőkének

Társadalmi töke: aktuális és potenciális erőforrások összessége, amelyek az egy csoporthoz tartozáson alapulnak:

Hitelképesség: az egyes csoporttagok által birtokolt tőke összessége, ami valamennyiük számára biztosítékul szolgál

Intézményesülési aktus: valamilyen közös név felvétele, ami valamilyen osztályhoz, családhoz, stb, tartozást jelent

Intézményesült kapcsolatok: intézményesülési aktus révén jön létre, a társadalmi tőkeviszonyról ad tájékoztatást.

Csereviszony: - a társadalmi tőke alapját képezik

- anyagi és szimbolikus szempontok szerint szerveződik

- nem korlátozódik teljesen földrajzi, gazdasági és társadalmi közelségre

A társadalmi tőke az emberek közötti kapcsolatokban megbúvó erőforrás, mely a kapcsolatok mennyiségének, minőségének és struktúrájának függvénye. $\mathrm{Az}$ emberi kapcsolatokban áramló energia elősegítheti az egyén boldogulását, de egyúttal elősegítheti a kollektív cselekvést is és ez által egy egészséges és prosperáló társadalom fenntartását.

A szociológusokat és antropológusokat már régóta foglalkoztatja a társadalmi hálózatok kérdése: miként szolgálnak a társadalmi kapcsolatok rendszerei a különböző feladatok elvégzésének eszközeiként, illetve hogyan biztosítanak rendet és adnak értelmet a társadalmi életnek. A fogalom a karrierjét a nyolcvanas években kezdte Pierre Bourdieu francia szociológus munkája által, de igazán népszerüvé James Samuel Coleman, majd Robert D. Putnam olasz, társadalmi tőkéről szóló műveivel vált. Bourdieu három tőkefajtát különböztetett meg: a gazdasági, a kulturális és a társadalmi tőkét. Ezen erőforrások birtoklását és továbbörökítését az úgynevezett szimbolikus tőke garantálja. Bourdieu elmélete szerint a tőkefajták birtoklása segíti az uralkodó osztályt hatalmának megtartásában a társadalmi élet különböző mezein. Bourdieu szerint a társadalmi tőke az azon erőforrások összessége, mely a kapcsolatok tartós, többé-kevésbé intézményesült rendszeréhez, más szavakkal egy bizonyos csoporthoz tartozáshoz kötődik. Az egyén által birtokolt társadalmi tőke nagysága egyrészt azon kapcsolatok hálójának kiterjedtségétől függ, amelyeket ténylegesen mozgósítani tud, másrészt azon másféle tőke nagyságától, amelyet azok birtokolnak, akikkel kapcsolatban áll. A csoporthoz való tartozás az egyén számára hitelképességet kölcsönöz, mert az egyes csoporttagok által birtokolt tőke összessége mindannyiunk számára biztosítékul szolgál. Coleman szerint a társadalmi tőke fogalma, mint a cselekvést elősegítő erőforrás a társadalmi struktúra bevezetését jelenti a racionális döntések paradigmájába. Coleman szerint a társadalmi töke az aktorok közötti kapcsolatok struktúrájában jelenik meg, ami bizonyos cselekvéseket segít elö. Coleman a társadalmi tőke három formáját mutatja ki. A társadalmi tőke megjelenik kötelezettségek és elvárások formájában, melyek a társadalmi környezet megbízhatóságán alapulnak. Másodsorban a társadalmi struktúra képessége az információ áramlás biztosítására, mely a társadalmi cselekvés alapját képezi. Harmadsorban a megfelelő szankciók rendszerével megerősített hatékony normák jelenléte. A társadalomban bizonyos aktorok szívességet tesznek másoknak, ilyenkor az előbbi elvárásokat fogalmazhat meg az utóbbival szemben, ez utóbbi lekötelezettjévé téve. Az ilyen típusú kapcsolatok fennmaradása a társadalmi környezetben meglévő bizalmon alapul, azaz hogy az adott „kölcsönt” „visszafizeti” a fogadó fél. Egy olyan társadalom, amelyben ,kihelyezett” szívességek száma minden időben nagy, a tagjai számára mozgósítható társadalmi tőke szintje magas marad. A társadalmi kapcsolatokban áramló információ is fontos formája a társadalmi tőkének. Az információ a cselekvés alapját képezi, 
de megszerzése költséges. A társas kapcsolatok jól használhatók fel információszerzésre mutat rá Coleman. (Szántó-Lengyel 1998)

A Garnovetteri társadalmi tőke koncepció a szociometriai és antropológiai hagyományban gyökerezik, és megállapítja, hogy a kapcsolatokból kinyerhető erőforrás mennyisége és minősége nagyban függ a kapcsolatháló szerkezetétől. Bevezeti a gyenge és erős kötések fogalmát. Két aktor közötti kötés erősségét az azt jellemző érzelmi töltés, és a ráfordított idő határozza meg. Megállapítja, hogy az egyént körülvevő klikk szoros kötésekkel kapcsolódik az egóhoz, és a kapcsolatoknak ebben a rendszerében a tranzitivitás szabálya az iránymutató, azaz nagy valószínűséggel, ha A barátja B-nek, és B barátja C-nek, akkor A barátja C-nek. Ebböl az is következik, hogy minél szorosabb kapcsolat van két aktor között annál nagyobb mértékben fog a két személy baráti köre egybe esni. A gyenge kötéseket ezzel szemben alacsony érzelmi intenzitás és alacsony idő ráfordítás jellemzi, a tranzitivitás követelménye pedig nem áll fent. Az ilyen gyenge kötések gyakran nyúlnak a csoporton kívülre: ezek a messzebbre nyúló gyenge kötések gyakran szolgálnak hídként, nemcsak az ego és ismeröse között, de rajtuk keresztül az őket körülölelő közeli barátok hálója között. (Szántó-Lengyel 1998)

A társadalmi tőke vizsgálata egyre inkább előtérbe került a társadalomtudományi kutatások területén. A hazai neveléstudományi kutatások tekintetében szeretnénk kiemelni Pusztai (2009) és Fényes-Pusztai (2004) munkáit. A társadalmi tőkehozam nemcsak a hallgatói eredményességben, hanem a munkaerőpiacon való elhelyezkedésben is mérhető. FényesPusztai (2004) A kulturális és a társadalmi tôke kontextuális hatásai az iskolában címü munkájukban, arra a következtetésre jutottak, hogy a diákok továbbtanulási terveit befolyásolja, hogy szüleik felsőfokú végzettségüek-e a vagy nem. Feltehetőleg a nagyobb kulturális tőke ambiciózusabb továbbtanulási terveket eredményez. Azonban felléphet kontextuális hatás is, méghozzá annak additív keresztező esete, azaz azokban az osztályokban, ahol több a diplomás szülő, mind az értelmiségi származásúak, mind a többi diák inkább választja a továbbtanulást, ráadásul a nem értelmiségi származásúakra húzó hatással van a környezet: ahol sok a diplomás szülő, több nem értelmiségi gyermek fogja vállalni a felvételi vizsga kockázatát.

Pusztai Gabriella (2011) A láthatatlan kéztől a baráti kezekig címü könyvében fontos, ám Magyarországon még nem kutatott kérdésekre (például arra, hogy az egyetemi pályafutás alakulásában milyen szerepet játszanak a társas kapcsolatok) keresi az elméletileg és empirikusan is megalapozott válaszokat. A diszkurzív cselekvésekben formálódó közösségeket és az ezekben születő normákat az egyetemi világ vizsgálatának látókörébe helyezi. Abból indul ki, hogy a kapcsolati struktúra legalább olyan fontos, mint a társadalmi struktúrában elfoglalt hely. Rámutat arra, hogy az egyetemi eredményesség, a hallgatók formálódó szakmai magatartása és kapcsolati világa között milyen összefüggések vannak. Egyértelmüvé teszi, hogy az olyan társas értékek, mint a figyelem, a szolidaritás, a támogatás nevelésszociológiailag értelmezhetö és értelmezendő kategóriák, mert az egyetem mindennapi müködésének, csoportviszonyainak a termékei. Nem egyszerüen csak "vannak" vagy "nincsenek" ezek az értékek, hanem a kapcsolatok közösen szőtt hálójában születnek. A felsőoktatás valamennyi szereplöjének közremüködésétől függ meglétük és erejük.

Lengyel-Szántó (1998) A gazdasági élet szociológiája címü munkájukban a rend interakcionális és kulturális alapjának weberi hangsúlyozására fókuszálnak. DiMaggio (1982) mérési modelljét használták és kimutatták, hogy a (Bourdieu nyomán „kulturális tőkének” nevezett) magas presztízsű kulturális erőforrások iránti középiskolás kori érdeklődés, illetve a velük kapcsolatos tapasztalat számos szempontból jelentős pozitív hatással van arra, hogy az illető hova jut el az iskolázottság és a házasság terén a fehér amerikai férfiak és nők körében egy 11 évvel később vett keresztmetszeti minta alapján. 
Vizsgálatuk középpontjában az állt, hogy a rendi kultúrában való részvétel milyen hatást gyakorol az iskolázottság elért szintjére és párválasztásra. A modern ipari társadalmak-ban a képzettség vált a foglalkozások megszerzésének elsődleges útjává. Különösen a felsőoktatás a döntő előfeltétele a legjövedelmezőbb és legbefolyásosabb gazdasági pozíciók megszerzésének. Bourdieu (1998) szerint az oktatási rendszernek tudható be, hogy a kiváltságos rendi kultúrában való részvételt olyannyira jutalmazzák. Számos olyan tanulmány született már az iskolázottság Amerikában játszott szerepéről, amely a kulturális tőkét próbálta mérni, illetve amely kísérletet tett a kulturális tényezők osztályhelyzettől való operacionális megkülönböztetésére.

\section{Az emberi töke}

Az emberi erőforrás szerepét a gazdasági növekedésre már a klasszikus közgazdaságtan képviselöi is felismerték. Legelöször (már a 17. században) William Petty alkalmazta ezt a kifejezést, és kísérletet is tett az emberi tőke értékének a meghatározására (Varga, 1998). Az emberi tőke elméletének képviselői az elmúlt mintegy fél évszázadban számos kutatással bebizonyították, hogy a humántőkének igen jelentős a szerepe a gazdasági növekedésre. Az emberi tőke elmélete alapján az oktatás, a képzés beruházásként értelmezhető, a beruházással nő az egyének termelékenysége, és a termelékenység-növekedés következtében emelkedik a keresetük is. Az oktatás és a képzés az emberi tőkébe történő beruházásnak csak egy-egy lehetséges formája, hiszen több olyan beruházás is ide sorolható, amely javítja az egyének termelő képességét. Tervezett kutatásunkban a képzésbe, oktatásba való bekapcsolódás munkaerő-piaci hatásait szeretnénk vizsgálni.

$\mathrm{Az}$ emberi tőke teóriájának első képviselői Schultz, Rosen, Coleman az emberi erőforrásokba és a fizikai tőkeállományba történő befektetések között kapcsolati viszonyt feltételezetek. Az emberi tőke koncepciójának első kidolgozója Schultz volt. Elmélete szerint a gazdaságilag racionálisan cselekvő egyénnek az emberi erőforrásba való beruházása a későbbiekben megtérül, oly módon, hogy a beruházás költségeit meghaladja annak haszna. A megtérülés egyik területe a munkaerőpiac. Schultz e gondolatkör mentén dolgozta ki az emberi tőke beruházás fogalmát. Az emberi töke beruházást a gazdasági növekedés motorjaként definiálta (Lengyel és Szántó 1998 idézi R. Fedor 2015).

Rosen szerint, ,az emberi tőke olyan tőke, melyet az emberek képességei és produktív ismeretei alkotnak" (Rosen 1998:71). Schultz ennél tágabb értelemben gondolkodott az emberi tőkét alkotó tényezőkről. A tudás megszerzésén, az oktatásba való befektetésen túl a fejlődés forrásának tekinti a javuló egészségi állapotot, a születéskor várható átlagos életkort, a csecsemőhalandóság csökkenését, a gyermeknevelésre fordított családi erőforrások növekedését (Schultz 1998 idézi R. Fedor).

Az emberi tőke elmélet szerint, az egyén az oktatásba, képzésbe történő bekapcsolódását egyfajta beruházásként értelmezi, melynek költségei ettől eltérő időpontban a munkaeröpiacon térülnek meg (Varga 1998 idézi R. Fedor 2015).

Fenti elméletek összegzéseként elmondhatjuk, hogy az emberi töke ez egyén ismereteinek és képességeinek összessége. Mikor az emberi tőkébe beruházunk, növeljük szakértelmünket, melynek előnyeit a munkaeröpiacon élvezhetjük. Amennyiben a munka világában történő érvényesülésünket az emberi tőke hozamaként fogjuk fel, úgy az emberi tőke termelése növeli az egyén alkupozícióját. Bár a szó klasszikus értelmében azt jelenti, hogy a rövidebb oldal elve értelmében azok vannak kedvezőbb helyzetben, azok alakítják a feltételeket a munkaeröpiacon, akik kevesebben vannak. Jelen esetben azt feltételezzük, hogy minél több emberi tőkére tesz szert valaki, annál inkább képes irányítani saját sorsát, annál inkább kizárhatja a külső korlátozó tényezőket a döntési mechanizmus során. Nem kell lejjebb adni a munkakörülményekkel, fizetéssel szemben támasztott igényéből. (R. Fedor 2015) 
Emberi tőke-beruházásnak tekinthetjük:

- alap- és magasabb fokú oktatást,

- munka közbeni képzést,

- munka közben elsajátított új tudást, ismereteket, tapasztalatszerzést,

- migráció

- egészségügyi kiadásokat,

- a munkaalkalmakkal kapcsolatos tájékoztatást.

Az emberi tőke elméletének központi magja az a gondolat, hogy az egyének nemcsak a jelenben elérhető élvezetek kedvéért költenek saját magukra, azaz vesznek igénybe például egészségügyi szolgáltatásokat, döntenek a továbbtanulás mellett, időt és energiát áldoznak a jobb munkalehetőségek felkutatására, hanem a jövőben realizálható pénzbeli és nem pénzbeli hozamok érdekében is (Blaug, 2007: 44).

Polónyi (2008), Az oktatás, oktatáspolitika, oktatásgazdaság tanulmányában többek között foglalkozik a felsőoktatási intézmények minőségértékelésével. A közgazdasági megközelítés szerint az értékelés legfontosabb indikátora a végzett hallgató alkalmazhatósága, azaz hogy a frissen végzett hallgató munkahelyet talál, ezáltal megtérül a tanulásba befektetett tőke. Fontos, hogy a végzett és elhelyezkedett hallgató mennyire érzi magát kompetensnek a munkahelyén, mennyire készítette fel az oktatási rendszer a munkájára. Több indikátorcsoportot vizsgál az oktatás minőségértékelésekor. Kiemeli, hogy a felsőoktatási akkreditációban használt akadémiai indikátorok helyett a külső hatékonysági indikátorokat lenne érdemesebb figyelembe venni. Polónyi István, Ujhelyi Mária (2013) a The impact of higher education on the economic integration and innovation munkájukban azt is bemutatják, hogy az egyetemeken szerzett tudás (expenditure effect, the knowledge effect) milyen formában gyakorol hatást a térség gazdaságára, és hogyan áramlik az üzleti életbe.

Győrgyi (2014), Az oktatás eredményei, haszna, megtérülése tanulmányában az oktatási eredményeket, hasznukat és az oktatás megtérülését jól mérhető indikátorokkal mutatja be, amik az eredményeket mutatják, de nem foglal állást abban a kérdésben, hogy a mért eredmény közvetlenül a tudásra, mint tőkére vezethető vissza, vagy pedig munkaerő-piaci folyamatokra. Arra fekteti a hangsúlyt, hogy milyen előnyökkel jár a munkaerőpiacon az oktatási rendszerben, tanulásban történő előrehaladás, illetve az oktatásba fektetett pénzek hasznosulását vizsgálja.

\section{Előfeltevések}

A szakirodalom vonatkozó tanulmányait alapul véve a következő előfeltevéseket fogalmazzuk meg:

- Azt feltételezzük, hogy az utolsó éves hallgatók/frissen diplomázott hallgatók elsősorban végzettségüknek megfelelő területen kívánnak elhelyezkedni illetve helyezkedtek el.

- Azt feltételezzük, hogy a hallgatói eredményesség és az elhelyezkedési mintázat között összefüggés van.

- Azt várjuk, hogy az érintettek elsősorban a hazai munkaerőpiacon kívánnak elhelyezkedni, s csak ennek kudarca esetén, második lehetőségként kerül előtérbe a külföldi munkavállalás lehetősége.

- Azt feltételezzük, hogy az érintettek társadalmi tőkéje meghatározza a munkaerő-piaci megjelenés jellemzőit (ezen belül a családon belüli társadalmi tökehatást valamint a különböző egyetemi szervezetekben való részvétel hatását kívánjuk mérni).

A társadalmi tőke elhelyezkedésre gyakorolt hatását a következő dimenziók mentén tervezzük mérni: a családon belüli társadalmi töke hatása az elhelyezkedésre. A családon belüli társadalmi tőke mérését Coleman nyomán a családszerkezet jellegével mérjük. Coleman a családban megjelenő emberi-, és társadalmi tőke komplementer szerepét 
hangsúlyozza a gyermekek fejlődése szempontjából. A szülők emberi tőkéje akkor elérhető a gyermekek számára, ha a szülők ténylegesen jelen vannak a család életében, illetve ha kellö figyelmet fordítanak a gyerekekre. Ezért a család szerkezetének hatása mellett a szülők iskolai végzettségének elhelyezkedésre gyakorolt hatását is vizsgálni szeretnénk.

Továbbá, a társadalmi tőkehatást a különböző egyetemi szervezetekben való részvétellel és annak hiányával kívánjuk mérni. (DETEP, Verzár Frigyes Szakkollégium, stb.)

\section{A vizsgálat alanyai (mintavétel)}

Vizsgálatunk alanyai a Debreceni Egyetem Egészségügyi Karának (valamint szükség esetén a hazai és külföldi egyetemek társkarainak) utolsó éves, valamint végzett Ápolás és betegellátás alapszakos ápoló, mentőtiszt és szülésznő valamint az Egészségügyi gondozás és prevenció alapszak védőnő hallgatói. Körükben teljes lekérdezést tervezünk.

Adatgyüjtés: empirikus munkánkban kvantitatív adatgyüjtési módszerrel dolgozunk, mivel a vizsgálni kívánt alapsokaság nagy létszámú, továbbá, mert általánosítható eredmények megfogalmazására törekszünk, illetve célunk a témához megfogalmazott előfeltevések, hipotézisek tesztelése.

Továbbá munkánk során a következő adatbázisokra kívánunk hangsúlyt fektetni: hazai adatbázis: DPR (Diplomás Pályakövető Rendszer), nemzetközi adatbázis EUROSTUDENT.

\section{Elemzés}

Az elemző munkát matematikai-statisztikai módszerrel dolgozzuk fel. A felállított előfeltevésekre fektetjük a hangsúlyt. A kialakított statisztikai modellek értelmezése révén reméljük a vizsgált populáció mélyebb megértését.

\section{Irodalom}

Blaug, (2007): Blaug, M. (2007): Az emberi tőke elmélete. Replika, 18. évf., 3. szám, 4356.p.

Bourdieu, P. (1998): Gazdasági tőke, kulturális tőke, társadalmi tőke. In: Lengyel GyörgySzántó Zoltán (szerk.): Tőkefajták: a társadalmi és kulturális erőforrások szociológiája. Budapesti Közgazdaságtudományi Egyetem, Aula Kiadó, Budapest, 155-176.

Coleman, J. S. (1996): A társadalmi tőke. In: Lengyel György - Szántó Zoltán (szerk). A gazdasági élet szociológiája. BKE Szociológiai és Szociálpolitikai Tanszék, Budapest, 99129.

Coleman, J. S. (1998): A társadalmi tőke az emberi tőke termelésben. In: Lengyel György-

Fényes Hajnalka - Pusztai Gabriella (2004): A kulturális és társadalmi tőke kontextuális hatásai az iskolában. Statisztikai Szemle 82 (június-július), 567-582.

Győrgyi Zoltán (2014): Az oktatás eredményei, haszna, megtérülése Budapest, Oktatáskutató és Fejlesztő Intézet.

Imre Anna (2001): Emberi és/vagy társadalmi töke. Educatio 3, 601-605. p.eröforrások szociológiája. Budapesti Közgazdaságtudományi Egyetem, Aula Kiadó, Budapest.

Net1: KSH adatbázis. Letöltés: 2016.11.10. Web: https://www.ksh.hu/docs/hun/xstadat xsta dat_eves/i_qlf045.html

Polónyi István - Ujhelyi Mária (2013): Part Three: Chapter 1: The impact of higher education on the economic integration and innovation, In: Szerk.: Makó Csaba, Szerk.: Polónyi István, Szerk.: Szanyi Miklós Organisational innovation and knowledge development: institutions, methodological foundations and empirical experiences. Budapest: Új Mandátum Könyvkiadó, 2013. pp. 176-215. (Oktatás és Társadalom; 15.)

Polónyi István (2008) Oktatás, oktatáspolitika, oktatásgazdaság. Nemzeti Tankönyvkiadó. 
Pusztai Gabriella (2009): A társadalmi tőke és az iskola. Kapcsolati erőforrások hatása az iskolai pályafutásra. Újmandátum Könyvkiadó, Budapest

Pusztai Gabriella (2011) A láthatatlan kéztől a baráti kezekig. Hallgatói értelmezőközösségek a felsőoktatásban. Új Mandátum Könyvkiadó. (Oktatás és társadalom 9.)

R. Fedor Anita (2015): Egyensúlyban? A munkaerő-piaci karriertől a familiarizmusig. A kisgyermeket nevelő nők munkavállalási attitüdje(i). Debrecen: Debreceni Egyetemi Kiadó, 2015. 252 p

Szántó Zoltán (szerk.): Tőkefajták: a társadalmi és kulturális erőforrások szociológiája. Budapesti Közgazdaságtudományi Egyetem. Aula Kiadó, Budapest, 11-44.

Varga Júlia (1998): Oktatás-gazdaságtan. Közgazdasági Szemle Alapítvány, Budapest 